\title{
RTAs and WTO Compatibility: Catch Me If You Can? The Case of EPA Negotiations
}

\author{
Lucian Cernat \\ UNCTAD \\ Bonapas Onguglo \\ UNCTAD \\ Taisuke Ito \\ UNCTAD
}

\begin{abstract}
There is an ongoing debate about best ways to assess the compatibility of RTAs with WTO rules and the possible negative impact that the proliferation of RTA formation may have on individual members and on the stability of the multilateral trading system as a whole. Therefore, rules defining the WTO compatibility of RTAs are one of the issues in the WTO Doha negotiations. Taking the current EPA negotiations between ACP and EU as an example, this paper examines two sorts of questions: ( $i$ ) the implications for developing country members of the current proposals to tighten the rules on WTO compatibility of RTAs; (ii) the impact that the proliferation of RTA formation may have on non-RTA members and on the stability of the multilateral trading system as a whole. More specifically, the paper assesses quantitatively using a partial equilibrium framework the implications for ACP countries of some of the proposals to reform GATT Art. XXIV, in particular the "substantially all trade" criteria. Based on a CGE approach, the paper then

\footnotetext{
*Corresponding address: The authors are Economic Affairs Officers with the United Nations Conference on Trade and Development (UNCTAD). The views expressed in this paper are those of the authors and do not necessarily reflect those of the UNCTAD secretariat. UNCTAD, Palais des Nations, 8-14, Av. de la Paix, 1211 Geneva 10, Switzerland, Lucian Cernat: Tel: +41(0)22 917 5496, E-mail: lucian.cernat@ ec.europa.eu
}

(2008-Center for International Economics, Sejong Institution, All Rights Reserved.
\end{abstract}


looks at the implications of EPA negotiations on third countries and its linkages with the ongoing Doha negotiations, in particular on how the future EPA agreements could be non-trade diverting, in line with Ohyama-PanagariyaKrishna version of the Kemp-Wan theorem.

- JEL classification: F13, F15, F17

- Key words: ACP, EPA, Kemp-Wan, partial equilibrium analysis, CGE, GATT Art XXIV

\section{Reforming the GATT Art. XXIV: Catch Me If You Can?}

Regional trade agreements (RTAs) continue to proliferate unabated in parallel, and apparently with greater success than the Doha round of multilateral negotiations. The exact number of RTAs currently in operation worldwide is not known precisely. However, various assessments (including WTO estimates) place the total number of RTAs between 250 and over 300. One reason for this proliferation is that RTAs are seen as an important development strategy for many developing countries to foster regional trade and economic integration. But, at the same time, RTAs have to be consistent with the WTO rules then prevailing in order to contribute to building an open, predictable and transparent equitable multilateral trading system. These new developments in RTA formation have led to a renewed interest in RTAs, with many academics questioning the impact RTAs have had on members and third countries.

In parallel with the proliferation of RTAs, the WTO members have been for the most part unable to use the provisions contained in Art. XXIV to reach consensus on whether an RTAs is compatible with WTO rules and principles or not. Furthermore, with a few notable exceptions (like the Turkey Textile case), WTO rules have not been used to <catch> those RTAs that fall short of the conditions imposed to make them compatible with the other WTO rights and obligations.

Therefore, given the systemic implications of RTA proliferation and de facto lack of enforceability of the current Art XXIV, and the ability of most WTO members to "free ride" on this relative legal deficit, WTO members agreed that one objective of the current round of negotiations should be the clarification and strengthening of the rules governing the WTO compatibility of RTAs. Hence as part of this process, several WTO members have submitted proposals for the strengthening of several critical aspects for the enforceability of Art. XXIV, such as "substantially all trade" (SAT) criteria, transition periods, etc. However, despite this 
clear mandate, the proposal made so far by various WTO members (in particular ACP countries, EU, Australia) are far from being consensual.

But, whereas negotiators have difficulties in applying or reforming the current WTO rules, there is a theoretical argument based on the Kemp-Wan theorem (and its subsequent extensions) prescribing a set of conditions that ensure the compatibility between multilateralism and regionalism. Kemp-Wan (1976), and subsequently Ohyama (1972) and Panagariya-Krishna (1997), inter alia, argued that for any proposed customs union or free trade area there exists a set of common external tariffs that would leave the new trading bloc's trade with non-member countries unchanged, so that the welfare of the latter countries would not be affected and any improvement to the welfare of the integrating countries would strictly add to world welfare. The Kemp-Wan model (1976) endogenises the setting up of the common external tariff after the formation of a customs union in such a way that it leaves unaffected the rest of the world. Under these conditions, with an endogenously chosen CET, a customs union would be welfare increasing leading to trade creation for members and no trade diversion for non-members. The original Kemp-Wan condition was further extended to the case of FTA formation by Panagariya and Khrisna (1997).

Hence, these theoretical results suggest that, when the post-RTA tariffs are endogenized along the lines of Kemp-Wan conditions, regionalism can be a "building block" for the multilateral trading system. ${ }^{1}$ Despite its appealing conclusions, the Kemp-Wan welfare-improving criterion for RTA formation is often considered of little practical value in the real world of trade negotiations, since RTA members usually do not lower their external tariffs vis-à-vis non-RTA members at the same time as the RTA formation. However, in the case under consideration in this paper, the simultaneous unfolding of both EPA and Doha negotiations, as well as the current debate on the reform of GATT Art. XXIV, offers an opportunity to consider whether the tariff cuts envisaged in the Doha round by EPA members would indirectly make EPAs Kemp-Wan compatible. Thus, the Kemp-Wan welfare-improving criterion becomes of direct relevance for the main issues raised earlier in the context of the GATT Art. XXIV reform, concerning the proliferation of regionalism in recent decades and the relationships between regional trade arrangements and the multilateral trading system.

The WTO negotiations on Art. XXIV are most relevant for the ongoing EPA

${ }^{1}$ See Bond et al. (2004) for a more detailed discussion of the specific conditions necessary for the "building bloc" scenario to be achieved. 
between ACP countries and the EU negotiations. From a development perspective, the EPAs are perhaps among the most significant RTAs currently under negotiation, judging by the number of countries and issues involved (special and differential treatment (SDT), deep integration measures and asymmetries between developing and developed country members, etc). ${ }^{2}$

Given its systemic and development importance, this paper takes the case of EPAs as an example to show the relevance of these theoretical predictions and to clarify two main issues. Firstly, the paper will assess the various proposals for Art XXIV reform and their implications for the EPA members. In particular, the paper looks at how to reconcile the more stringent criteria put forward by certain WTO members with the recognized principles of "less than reciprocity" and special and differential treatment for developing countries. Secondly, to respond to the concerns of non-members, the paper will assess the Kemp-Wan admissibility of the proposed EPAs in the context of the Doha negotiations.

Consequently, the paper is organized as follows. The next section presents briefly the three reform proposals made by the ACP, EU and Australian proposals and their main features (SDT, SAT requirements). Based on this discussion, section 3 uses a partial equilibrium framework to assess the degree of flexibility under different Art. XXIV reform proposals and identify potential sensitive sectors for ACP countries. In section 4 the attention turns to the impact of EPA formation on non-members and how potential trade diversion could be eliminated. In doing so, this section uses a CGE model with endogenous tariff formation to calculate the amount of trade liberalization that EPA members need to undertake vis-a-vis nonmembers in the context of the ongoing Doha negotiations, in line with the KempWan theorem. Section 5 concludes by offering several recommendations that could reconcile the existing proposals for reform of GATT Art. XXIV.

\section{What Do the WTO Negotiators Propose?}

Several WTO members have submitted proposals for the strengthening of a number of critical aspects for the enforceability of Art. XXIV, such as "substantially all trade" (SAT) criteria, transition periods, etc. One of the most

\footnotetext{
${ }^{2}$ However, in terms of the economic value of such preferences, the relative importance of EPAs is less evident. See for instance Brenton et al. (2007) for an argument suggesting that that value of preferences granted to developing country exporters under EPAs is likely to be marginal in the absence of other supportive measures, such as Aid for Trade.
} 
stringent proposals for measuring SAT compatibility was submitted by Australia. The Australian proposal suggests a tariff line measurement of SAT (with some trade volume criteria) that is based on a benchmark comprising the elimination of duties of at least_70 per cent of all tariff lines at HS six digit level on entry into force of an agreement, and 95 per cent of all tariff lines at HS 6-digit levels 10 years following the enactment of the agreement. The Australian proposal further argues to interpret SAT as requiring no exclusion of any "highly traded" products ${ }^{3}$ and "significant exports". ${ }^{4}$ In contrast, the EU suggested to base the measurement of SAT on a trade coverage approach based upon the aggregate total bilateral trade of RTA partners (rather than individually), as opposed to a tariff line approach. It has subsequently conceded that any future SAT benchmark should derive from the calculation of the combined average of both methods.

At the same time, ACP countries made proposals that try to promote greater flexibility in the application of Art. XXIV compatibility criteria to agreements involving developing countries. Therefore, one important question that is raised by the current efforts to reform the GATT Art. XXIV is how to reconcile, on the one hand, the attempt by the ACP countries to introduce flexibility and SDT as part of the assessment of WTO compatibility, with the other proposals to strengthen and clarify the rules applicable to RTAs under GATT Art. XXIV, in particular to the SAT requirement.

Hence, the next section will assess, in a preliminary fashion, the impact of various SAT proposals on ACP States by using a partial equilibrium methodology to assess the likely impact of EPAs on trade creation, tariff revenue implication, consumer surplus, and welfare etc. Based on this methodology, it will be possible to see the extent to which more stringent SAT requirements, like the ones proposed by Australia, will reduce the flexibility needed by ACP countries in EPA negotiations.

\section{Assessing the Current Negotiating Proposals - the Case of Tanzania}

There are several possibilities, including CGE modelling to assess the WTO compatibility of RTAs. For instance, Keck et al. (2005) have used the GTAP model

\footnotetext{
3“"Highly traded" products are defined as HS 6-digit tariff lines accounting for at least 0.2 per cent of total imports from RTA partners or alternatively those ranked among the top 50 imports of each RTA party.

4"Significant exports" are defined as those HS 6-digit tariff lines accounting for at least 2 percent of a party's total global exports in value.
} 
to estimate the impact of the EPAs on the SADC sub-region in a very comprehensive manner. Karingi et al. (2005) is another example of valuable analysis of the economic impact of EPAs. But the high level of product and country aggregation reduces the usefulness of most CGE modelling in estimating the impact of various specific proposals made by WTO members in the context of the current negotiations. ${ }^{5}$

Therefore, to assess these proposals, we use a partial equilibrium framework to assess the implications of EPA compatibility with various SAT criteria on the trade and development prospects of ACP countries, taking Tanzania as an illustrative example, using the SMART model. The methodology outlined in this section could be applied in a similar fashion to any ACP country or regional integration subgrouping that is in the process of negotiating an EPA with EU. There is a notable distinction to be made between compliance with SAT criteria at national and subregional level. Hence, the various benchmarks that trade policy makers could consider during EPA negotiations need to be assessed at both the national and subregional level. For instance, Tanzania belongs to the customs union created under the East African Community (EAC). Therefore the analysis outlined below could be carried out at EAC level, to see whether an EAC exclusion list would pass the scrutiny under the different disciplines as proposed by Australia.

Alternatively, the analysis could be carried out at the national level by EAC member and then consolidated and aggregated at the EAC level. The latter route would be better equipped to take into account the special characteristics and priorities at the national level, but it could also lead to conflicting national positions on "sensitive products" that would need to be harmonized at the EAC level. As this paper simply intends to illustrate the methodology that could be applied by all ACP countries and sub-regional groupings concerned, rather than provide comprehensive results for each EPA currently under negotiation, the current section will be confined to the analysis of the Tanzanian case at national level.

\section{The SMART Model}

SMART is a simple ex ante partial equilibrium model, measuring the first-round impact of trade policy changes. The SMART model provides for several effects of trade policy reforms to be estimated: (i) trade creation effect resulting from the changed level of domestic demand for imports from a particular trading partner

${ }^{5}$ Recent CGE analyses however have been conducted at a very disaggregate level using a mixed global and partial equilibrium methodology (Grant, Hertel, and Rutherford, 2007). 
caused by the changed price of the imported good after the tariff change, ${ }^{6}$ (ii) trade diversion effect - the substitution of goods coming from one foreign supplier with goods from the new preferential trade partner; (iii) the total trade effect is obtained simply by summing together the trade creation and trade diversion effects. The model can also take into account a price effect on exports. However, if the export supply elasticity is infinite then there is no price effect on exports; (iii) revenue effect - the SMART model can also estimate the revenue effects. The percentage change in revenue is equal to the percentage change in exports plus the percentage change in prices; (iv) welfare effect arises from the benefits consumers in the importing country derive from the lower domestic prices after the removal or reduction of tariffs. The net welfare gain is normally estimated as the increase in import value times the average between the ad valorem incidence of the trade barriers before and after their elimination.

Unlike the general equilibrium analyses, the model does not account for economywide effects of trade liberalization or inter-industry effects. However, the advantage of partial equilibrium model is the very detailed level of analysis, in line with the current WTO negotiations on Art XXIV reform. Working at this disaggregated level the SMART model allows considerable precision in identifying sensitive products and countries affected by the EPAs. ${ }^{7}$

Several criteria were taken into account to assess the likely impact of various EPA scenarios, based on several SAT requirements that are currently under discussion at the WTO:

- 80 per cent liberalization of current EPA trade flows (the EU proposal)

- 70 per cent liberalization of tariff lines (the Australian proposal)

- 95 per cent liberalization of tariff lines at the end of interim period (the Australian proposal)

- Accounting for "highly trade products" (the Australian proposal)

- Accounting for "significant exports" (the Australian proposal)

In order to assess the impact of the Australian definition of SAT on the way in which EPAs could be designed so that economic benefits are maximized, several additional steps are required. The EU trade profile has to be scrutinized in order to identify "highly traded" and "significant exports". The "highly traded" products

\footnotetext{
${ }^{6}$ SMART assumes a full tariff rate pass-through so that any particular tariff cuts would be fully reflected in the price change, i.e. that the benefits of the tariff change would be passed on to consumers.

${ }^{7}$ For a comprehensive description of the SMART model see Laird and Yeats (1986).
} 
would vary on a case by case basis, depending upon the ACP sub-grouping in question. The EU "significant exports" will nevertheless be common to all EPAs.

Using the SMART simulations, these SAT criteria suggested in different proposals under discussion at WTO, and their impact on the EPA liberalization scenarios, can be assessed against various benchmarks that trade policy makers could consider during EPA negotiations. For instance, ACP countries could try to shape EPAs in such a way that the likelihood for import surges is minimized. Similarly, some ACP countries and subgroups could be interested to know which liberalization scenario minimizes tariff revenue losses. Lastly, one might be interested in identifying products that would lead to maximization of welfare and consumer surplus.

Three benchmarks were used to select the "sensitive" products that could still be protected under the EPA in the case of Tanzania: (i) import surges; (ii) tariff revenues; (iii) welfare and consumer surplus effects. For each benchmark, both the EU and Australian SAT requirements were taken into account, to assess whether such requirements would effectively reduce the "policy space" needed by ACP countries and sub-groupings in EPA negotiations.

Another approach to identify "sensitive products" while complying with SAT requirements is to identify those products that have the highest level of tariff protection (Stevens and Kennan, 2005).

\section{A. Simulation Results}

\section{Import Surges and Adjustment Costs}

As mentioned before, one benchmark that ACP States could use to tailor their negotiation positions under EPAs would be to ensure that unsustainable import surges, likely to impose significant adjustment costs to their economies are minimized. As a proxy for products and sectors likely to face such major adjustment costs, we identify "sensitive" products that have the highest increase in trade flows, while complying with the various SAT conditions, e.g. 80 per cent of initial trade flows (the EU proposal), 70 per cent of tariff lines at the entry into force (Australian proposals), etc.

Import surge minimization can be done either with regard to: (i) overall imports, in which case absolute import surge values would be used, or (ii) a line-by-line approach, targeting for protection those products with the highest in-line import surge, compared to their original levels.

An overall import surge criterion would rely on a neutral cross-sectoral approach, where product-specific import surges are compared against overall estimated 
Table 1. Tanzania - "Sensitive Products" Minimizing Overall Import Surges

\begin{tabular}{|c|c|c|c|c|c|}
\hline Description & HS Code & $\begin{array}{l}\text { Imports before } \\
\text { EPA }(\$ 000)\end{array}$ & $\begin{array}{l}\text { per cent of total } \\
\text { imports }\end{array}$ & $\begin{array}{l}\text { Import increase } \\
\qquad(\$ 000)\end{array}$ & $\begin{array}{l}\text { as a per cent of } \\
\text { total import } \\
\text { increase }\end{array}$ \\
\hline Crude materials, inedible, except fuels & 630900 & 31,356 & $3.0 \%$ & 2,796 & $5.2 \%$ \\
\hline Food and live animals & 210690 & 20,980 & $2.0 \%$ & 1,609 & $3.0 \%$ \\
\hline Machinery and transport equipment & 870323 & 43,128 & $4.1 \%$ & 1,540 & $2.8 \%$ \\
\hline Machinery and transport equipment & 851780 & 6,813 & $0.7 \%$ & 1,363 & $2.5 \%$ \\
\hline Machinery and transport equipment & 870422 & 15,263 & $1.5 \%$ & 1,210 & $2.2 \%$ \\
\hline Manufact goods classified chiefly by material & 401120 & 20,721 & $2.0 \%$ & 1,199 & $2.2 \%$ \\
\hline Machinery and transport equipment & 851750 & 17,739 & $1.7 \%$ & 1,150 & $2.1 \%$ \\
\hline Machinery and transport equipment & 843149 & 40,452 & $3.9 \%$ & 1,143 & $2.1 \%$ \\
\hline Machinery and transport equipment & 870423 & 9,276 & $0.9 \%$ & 936 & $1.7 \%$ \\
\hline Subtotal & & 205,729 & $20 \%$ & 12,947 & $24 \%$ \\
\hline Memo item: total imports by Tanzania & & $1,043,056$ & & 54,258 & \\
\hline
\end{tabular}

Source: Authors' calculations, based on SMART 
import surges. By doing so, products with the largest absolute import increase would be considered "sensitive". Since many of these products would also have pre-EPA high levels of imports, an absolute import surge criterion would limit the list of "sensitive product".

When using such an overall import surge approach, in the case of Tanzania for instance, avoiding likely import surges under the 20 per cent exclusion benchmark (EU proposal), results in only 9 HS6 products being targeted (Table 1). As the simulation results reported below suggest, by earmarking these 9 products (with import increases ranging from 1.7-5.3 per cent) as "sensitive", it would allow Tanzania to protect its domestic market from import surges worth of \$US13 million (24 per cent of total estimated import surges) and \$US7.2 million in forgone tariff revenue ( 25 per cent of total tariff revenue losses). However, at the same time, by applying this criterion Tanzania is also deprived of more than \$US 2 million in consumer surplus, i.e. 28 per cent of the total estimated consumer surplus.

This suggests that, under this scenario, Tanzania will comply with SAT by the EU benchmarks, but not necessarily with the Australian proposal. The Australian proposal would require EPA members to liberalize at least 70 per cent of tariff lines at the entry into force of the agreement, a condition that Tanzania could clearly fulfill, while applying the import surge minimization criterion. Tanzania would also comply with the Australian suggestion for end-of-the-period EPA coverage.

However, further investigations should be performed to ensure that Tanzania complies with other requirements, such as liberalization of all "highly traded" products (i.e. products where EU import shares are higher than 0.2 per cent), as well as "significant exports" (i.e. products accounting for more than 2 per cent in total EU exports) by the end of the 10-year transition period for the EPA agreement.

What would these additional criteria suggested by the Australian proposal mean for the ways EPAs are negotiated? Let's look firstly at EU "significant exports". The Australian proposal requires that products at HS-6 digit accounting for more than 2 per cent of total EU exports to the world should not be excluded from EPA liberalization. When looking at the actual EU export pattern in 2004, for instance, only 3 products will be affected by this new additional criterion: Medicines, Other (HS code 300490); Motor vehicles (HS codes 870323 and 870332). As EU "significant exports" are common across all EPA partners, this criterion is unlikely to impose major difficulties, at least in terms of number of products to be liberalized, to any ACP country. In the case of Tanzania, for instance, these three "significant exports" represent 6.6 per cent of total Tanzanian imports from EU and simulation 
results suggest that their full liberalization would increase current import levels of these products by only 3 per cent. ${ }^{8}$

Yet, the "significant export" criterion will not allow Tanzania to include motor vehicles (HS code 870323) among its "sensitive products" by the end of the transition period, as this is one of the EU "significant export", based on present trade values. ${ }^{9}$ However, Tanzania (or other ACP countries or groupings) could ask for flexibility on this item and use the past experience with motor vehicles liberalization under other agreements negotiated by the EU, like the EU-Mexico FTA for instance as a precedent.

Let us now turn to the case of "highly trade products". The "highly traded products" criterion, in the case of Tanzania, would require the liberalization of some 99 products where imports from EU account for more than 0.2 per cent of total EU exports to Tanzania. A close inspection of the affected products shows that, when using this additional criterion all "sensitive products" identified in Table 1 would need to be liberalized. In the case of Tanzania, this additional criterion does not lead to major import competition from these particular tariff lines, nor does it have major implications for the overall competitiveness of the economy. However, if the "highly traded products" criterion is applied Tanzania will lose its ability to apply the overall import surge benchmark, which had a significant tariff revenue implications. The more general point to be made however is that, depending on the specific trade profiles of each ACP country or sub-regional group concerned, the "highly traded products" has the potential to reduce the policy options currently available to tailor the EPAs based on overall import surge minimization.

When a line-by-line import surge minimization is taken as a selection criterion for the products representing 20 per cent of total trade flows, much more products would be considered "sensitive". In the case of Tanzania, simulation results suggest that 486 HS6 product lines, i.e. 33 per cent of tariff lines, with import increases ranging from 8-89 per cent, could be excluded from liberalization. ${ }^{10}$ This would

\footnotetext{
${ }^{8}$ It should be noted that motor vehicles face an MFN applied tariff of 25 per cent in Tanzania, whereas medicines face only a 5 per cent tariff.

${ }^{9}$ However, if trade patterns change sufficiently enough during the transition period, EU "significant exports" might be different at the end of the period and motor vehicles could still be maintained as "sensitive products" by Tanzania.

${ }^{10}$ The highest import surges are witnessed by products in HS chapters 94,95 , and 96, all of them with initial levels of imports well below the average levels.
} 
reduce by 58 per cent the total import surges and by 52 per cent the tariff revenue losses, compared to the overall import surge approach. On the other hand, when these products are considered "sensitive", consumers will be deprived of 67 per cent of total consumer surplus likely to be generated by EPA.

The line-by-line import surge minimization benchmark in Tanzania favours a scenario that is fully compatible with the "significant export" criterion, as there is no common product among "sensitive products" and EU "significant exports".

But unlike the overall import surge approach, it seems that a liberalization scenario based on a line-by-line criterion for "sensitive products" would not comply with one of the additional conditions suggested by the Australian submission, i.e. liberalization of 70 per cent of tariff lines at the entry into force of EPA, unless some 10 per cent of the "sensitive products" previously identified are liberalized as well. Furthermore, as in the case of overall import surge benchmark, the line-byline benchmark does not fulfill the "highly traded products" criterion. Out of 486 "sensitive products" identified previously, 21 products cannot be maintained as "sensitive" (Table 2).

Although they represent a relatively small number of the total "sensitive products" list and have below average trade increases, these 21 products account for more than half of the trade covered by the initial "sensitive" list.

Several conclusions can be drawn from the impact assessment based on import surge benchmarks used above. Overall, if the Tanzanian case used as an illustration above is representative for other ACP countries or sub-groupings, then it seems that under a cautious liberalization logic a line-by-line approach is more appro- priate in tailoring EPAs to the specific development needs of ACP States than using an overall import surge criterion. However, in both cases, the "highly traded products" criterion is a major constraint, particularly in the case of overall import surge benchmark where all original "sensitive product" would be incompatible with this criterion. Even in the case of line-by-line approach, half of the initial trade covered by "sensitive products" would have to be subject to EPA liberalization.

\section{Tariff Revenue Losses}

As pointed out in the literature, another benchmark for the "sensitive products" that can be excluded from liberalization is to minimize tariff revenue losses. Unlike the case of import surges where different economic objectives could be targeted under an overall versus line-by-line approach, in the case of tariff revenue 
Table 2. Tanzania - "Sensitive" and "Highly Traded Products" under the Line-by-line Import Surge Benchmark

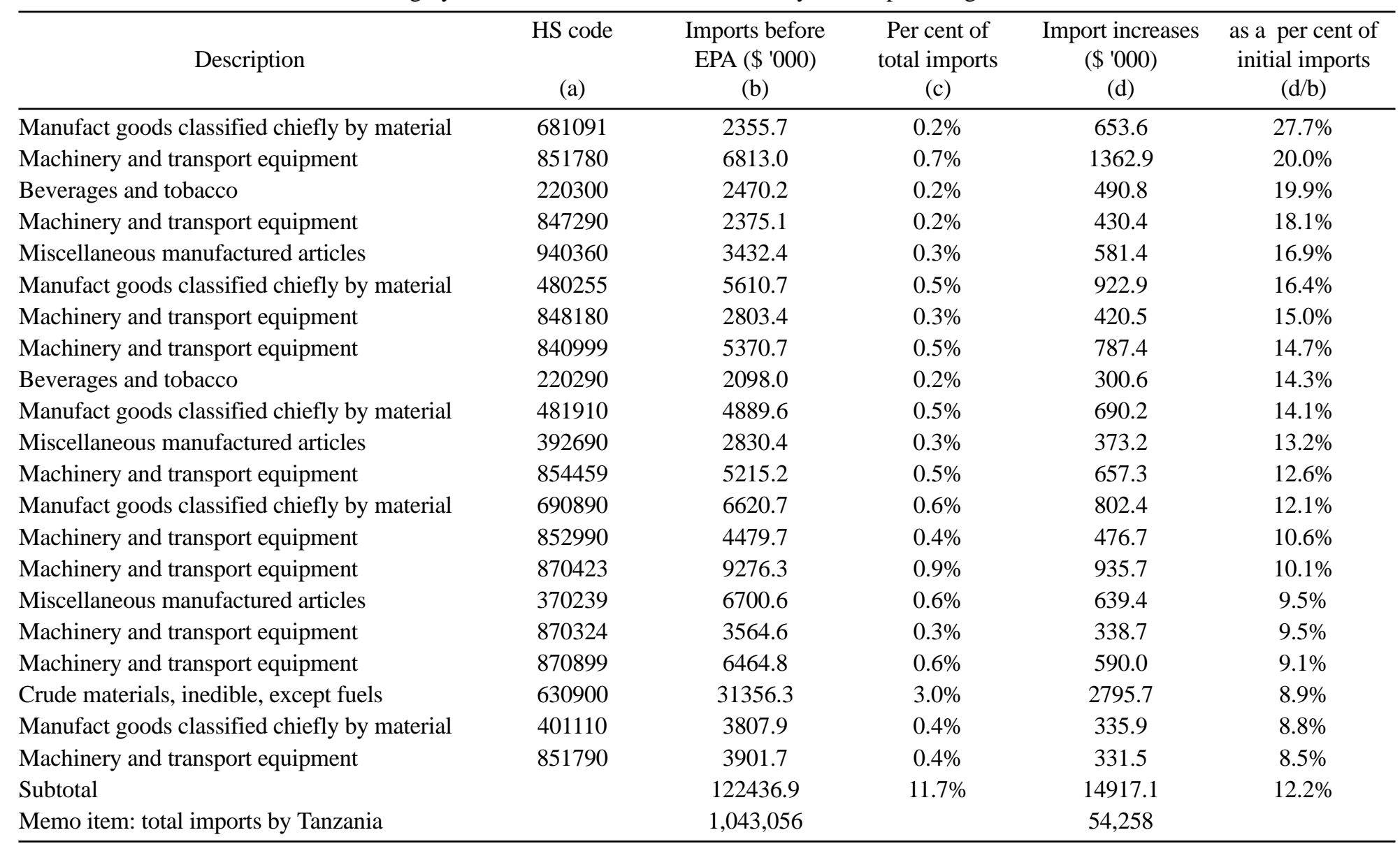

Source: Authors' calculations, based on SMART simulation results. 
Table 3. Tanzania - "Sensitive Products" Minimizing Tariff Revenue Losses

\begin{tabular}{|c|c|c|c|c|}
\hline Description & $\begin{array}{c}\text { HS } \\
\text { code }\end{array}$ & $\begin{array}{c}\text { Imports } \\
\text { before EPA } \\
\left(\${ }^{\prime} 000\right)\end{array}$ & $\begin{array}{c}\text { Import } \\
\text { increase } \\
(\%)\end{array}$ & $\begin{array}{c}\text { Tariff revenue } \\
\text { losses } \\
(\$ \text { '000) }\end{array}$ \\
\hline Crude materials, inedible, except fuels & 630900 & 31356.3 & $9 \%$ & -2118.61 \\
\hline Food and live animals & 210690 & 20979.7 & $8 \%$ & -1544.79 \\
\hline Machinery and transport equipment & 843149 & 40452.2 & $3 \%$ & -1095.84 \\
\hline Manufact goods classified chiefly by material & 480255 & 5610.7 & $16 \%$ & -735.24 \\
\hline Manufact goods classified chiefly by material & 481910 & 4889.6 & $14 \%$ & -573.53 \\
\hline Machinery and transport equipment & 870323 & 43128.0 & $4 \%$ & -557.56 \\
\hline Beverages and tobacco & 220300 & 2470.2 & $20 \%$ & -530.68 \\
\hline Food and live animals & 110710 & 7341.6 & $7 \%$ & -512.74 \\
\hline Machinery and transport equipment & 851780 & 6813.0 & $20 \%$ & -511.34 \\
\hline Manufacture goods classified chiefly by material & 690890 & 6620.7 & $12 \%$ & -506.03 \\
\hline Machinery and transport equipment & 870422 & 15263.5 & $8 \%$ & -503.51 \\
\hline Manufact goods classified chiefly by material & 681091 & 2355.7 & $28 \%$ & -497.57 \\
\hline Miscellaneous manufactured articles & 370239 & 6700.6 & $10 \%$ & -486.38 \\
\hline Machinery and transport equipment & 854459 & 5215.2 & $13 \%$ & -458.49 \\
\hline Subtotal & & $199,196.95$ & & $-10,632.31$ \\
\hline$\%$ of grand total & & $19.1 \%$ & & $36 \%$ \\
\hline
\end{tabular}

Source: Authors' calculations, based on SMART

loss minimization, this distinction becomes irrelevant. The policy objective of ACP countries would therefore be the minimization of overall tariff revenue losses. Following this criterion in the case of Tanzania, the simulation results have led to the identification of the following "sensitive" products (Table 3). However, this liberalization scenario would be completely unfeasible if the "highly traded products" criterion is applied as suggested by the Australian WTO proposal, thus reducing in a very significant way the flexibility sought by ACP countries in EPA negotiations and nullify the SDT proposal under the GATT Art. XXIV reform.

When compared with the EU "significant exports" criterion, with the exception of one product (machinery and transport equipment - HS code 870323) all other products can be included on the sensitive list. The sensitive products obtained based on tariff revenue loss minimization could also comply with the requirement for 70 per cent initial liberalization levels. Thus, ACP countries can minimize tariff revenue losses while at the same time complying with several SAT criteria, with the exception of "highly traded products". 


\section{Welfare and Consumer Surplus Maximization}

One of the main expected benefits of trade liberalization is welfare improvement and increases in consumer surplus, as a result of lower prices and presumably better quality products originating in the EU, once the EPA is in place. Therefore one of the benchmarks trade policy makers could consider is to ensure that trade liberalization leads to consumer surplus maximization, when various SAT requirements are applied conservatively. ${ }^{11}$ Thus, under the EU SAT approach (i.e. 80 per cent of initial trade flows), if consumer surplus is taken as a benchmark to be maximized then the simulation results identified 383 products yielding the highest consumer surplus. These products should therefore be considered as "priority products" to be liberalized, if consumer welfare is to be maximized.

However, when the additional criteria suggested by Australia are taken into account, several changes occur. Thus, based on the "highly traded products" criterion, an additional set of 98 products with low consumer welfare effects would have to be liberalized, adding very little to the overall development impact of EPAs. Furthermore, given that a large majority of products would not be required to be liberalized under this benchmark, the 70 per cent tariff line criterion would not be fulfilled. That criterion would require the liberalization of further 548 tariff lines.

In sum, given the rather skewed current import structure of Tanzania from EU, the consumer welfare benchmark could reach relatively high levels with relatively low levels of liberalization by Tanzania, judging in particular the Australian SAT requirements. Therefore, one could imply that the developmental impact of EPAs, at least from a consumer welfare perspective, can very well be achieved while preserving sufficient "policy space" in terms of EPAs negotiations.

\section{Combining Various Benchmarks}

Given that various benchmarks, each following a rather different economic rationale, could be used to identify "sensitive products" while complying with SAT requirements, one useful exercise would be to single out products that could at the same time lead to the attainment of multiple benchmarks. For instance, in the case of Tanzania, products included in Table 4 are common both on the "sensitive products" list that would minimize import surges, as well as "sensitive products" minimizing tariff revenue losses. These products, accounting for 7 per cent of initial Tanzanian imports from the EU, would reduce total potential import surges by 17 per cent,

\footnotetext{
${ }^{11}$ In theory, based on this criterion, ACP countries should liberalize 100 per cent of their trade with EU from the entry into force of the agreement.
} 
Table 4. Tanzania-Common "Sensitive Products" Minimizing Import Surges and Tariff Revenue Losses

\begin{tabular}{|c|c|c|c|c|c|c|}
\hline Description & $\begin{array}{l}\text { HS } \\
\text { code }\end{array}$ & $\begin{array}{c}\text { Imports } \\
\text { before EPA } \\
\left(\${ }^{\prime} 000\right)\end{array}$ & $\begin{array}{l}\text { As a } \% \text { of } \\
\text { total } \\
\text { imports }\end{array}$ & $\begin{array}{l}\text { Import } \\
\text { increase } \\
\left(\${ }^{\prime} 000\right)\end{array}$ & $\begin{array}{l}\text { As a } \% \text { of } \\
\text { initial in-line } \\
\text { imports }\end{array}$ & $\begin{array}{l}\text { Change in } \\
\text { revenue } \\
\left(\${ }^{\prime} 000\right)\end{array}$ \\
\hline Beverages and tobacco & 220300 & 2470.169 & $0.2 \%$ & 490.787 & $20 \%$ & -530.675 \\
\hline Miscellaneous manufactured articles & 370239 & 6700.6 & $0.6 \%$ & 639.37 & $10 \%$ & -486.383 \\
\hline Manufact goods classified chiefly by material & 480255 & 5610.721 & $0.5 \%$ & 922.908 & $16 \%$ & -735.241 \\
\hline Manufact goods classified chiefly by material & 481910 & 4889.552 & $0.5 \%$ & 690.151 & $14 \%$ & -573.525 \\
\hline Crude materials, inedible, except fuels & 630900 & 31356.303 & $3.0 \%$ & 2795.744 & $9 \%$ & -2118.614 \\
\hline Manufact goods classified chiefly by material & 681091 & 2355.694 & $0.2 \%$ & 653.583 & $28 \%$ & -497.565 \\
\hline Manufact goods classified chiefly by material & 690890 & 6620.652 & $0.6 \%$ & 802.367 & $12 \%$ & -506.033 \\
\hline Machinery and transport equipment & 851780 & 6813.004 & $0.7 \%$ & 1362.916 & $20 \%$ & -511.343 \\
\hline Machinery and transport equipment & 854459 & 5215.245 & $0.5 \%$ & 657.303 & $13 \%$ & -458.494 \\
\hline
\end{tabular}

Source: Authors' calculations, based on UNCTAD SMART simulation results 
while at the same time reducing total tariff revenue losses by 22 per cent. Yet, joint optimization of several benchmarks is not always a straightforward exercise of comparing previously determined "sensitive products" under each benchmark. For instance, if trying to jointly optimize two other benchmarks (e.g. maximizing consumer welfare and minimizing tariff revenue losses) there is no common "sensitive product" that could do both.

Another alternative approach to joint optimization is to maximize the net trade creation effect, given that in doing so several criteria (e.g. tariff revenue loss, consumer and producer surplus) are jointly optimized. Maximizing net trade creation effects offer a relatively simple way to mitigate various, often divergent, economic objectives that ACP countries should pursue during EPA negotiations. In the case of Tanzania, for instance, taking trade creation as a benchmark for selecting "sensitive products" identifies 234 products at HS6 level that, in the case of consumer welfare, would not be included in the "sensitive products" category.

\section{Making EPAs Kemp-Wan Compatible}

So far we have seen what the various proposals to reform the GATT Art XXIV are, both from a developmental perspective (ACP proposal) and to make it more operational (Australian proposal). We have also seen what specific elements of the various proposals, i.e. the SAT requirement could mean for a developing country engaged in a complex negotiation of a North-South RTA.

As mentioned earlier, one of the rationales to tighten the WTO rules applicable to RTA formation and the evaluation of their compatibility was the concern of some WTO members that the surge in RTA formation might lead to a "stumbling block" effect and implicitly to a deterioration of global welfare. Therefore, one important question refers to the conditions that would render EPAs welfareincreasing, in the sense of the Kemp-Wan theorem. For this purpose, a CGE framework can be applied to obtain the endogenous tariffs needed to maintain the import levels from non-EPA members constant and thus eliminate trade diversion.

As Gilbert and Wahl (2001) noted, the Kemp-Wan admissibility of RTAs has rarely been tested in a CGE context. Apart form Gilbert and Wahl (2001), that look at this issue in the context of several RTAs in the Asia-Pacific, Waschik (2005, 2006) also assesses the implications of Kemp-Wan conditionality of Australia-US FTA and China-Australia FTA. Gilbert and Whal (2001) found that, by endogenizing the external tariffs of RTA members, it is possible to create RTAs that are globally 
welfare-improving. They also found that the estimated welfare impact on members was smaller under the Kemp-Wan rule than with exogenous tariffs, and that in some cases the welfare implications for some RTA members are negative (under both Kemp-Wan or standard assumptions).

Waschik (2005, 2006) performs similar CGE analyses with endogenous tariffs to estimate the Kemp-Wan tariff reductions needed in the case of US-Australia FTA and China-Australia FTA. He also carries out a sensitivity analysis with regard to Armington elasticities and he found that tariff changes necessary to eliminate trade diversion are quite robust to changes in the Armington elasticity. The following section assesses the Kemp-Wan compatibility of EPAs, using a CGE model with endogenous tariffs.

\section{A. Model, Data and Simulation Scenarios}

The CGE model used to estimate the Kemp-Wan endogenous tariffs is that developed under the Global Trade Analysis Project (GTAP) as described in Hertel (1997). GTAP is a widely used ex-ante evaluation tool for trade policy analysis. The paper uses the standard static, perfect competition, constant returns to scale version of GTAP. The original GTAP6 database is aggregated in 20 regions and 19 sectors (see annexed tables for details). Within each region, consumers have the same non-homothetic preferences, according to which they allocate income between private consumption, public consumption and savings. Products originating from different countries are perceived as different by consumers (Armington differentiation). The elasticity of substitution between any pair of domestic and imported goods is constant within each sector, and the elasticity of substitution between each pair of imported goods originating from different countries is twice higher than that between domestic and foreign goods. The production side of the model assumes fixed production coefficients between primary inputs and intermediate inputs. As for intermediate inputs, they are also assumed to be 'Armington differentiated', with constant substitution elasticities. Production factors are fully employed. Labour is mobile across sectors and immobile internationally. Households' savings finance investment, and investment does not affect the current capital stock. Countries can borrow and lend abroad. The global primary factor price index is used as numeraire.

The database used in the simulations is the GTAP version 6. As mentioned in the documentation of the GTAP 6 database, protection data includes now a large number of existing RTAs, including the current ACP-EU preferential regimes, i.e. ACP, EBA, GSP). The original GTAP6 database was updated from the 2001 base 
year, to take into account EU enlargement and existing WTO commitments.

Four simulation scenarios are tested: two base scenarios and two Kemp-Wan scenarios. The first scenario (base1) assumes the elimination of tariffs between the EU and each of the EPA regions. Given that in many cases the intra-ACP trade is not fully liberalized, in the second scenario (base2), in addition to these tariff elimination, intra-ACP trade is also liberalized (e.g. intra-SADC, COMESA, CEMAC, Caribbean, etc). For these two simulation scenarios the 'standard' GTAP closure is adopted: total world savings add up to total world investment and expected rates of returns on savings are equalized across world regions. The trade balance of different regions is thus determined endogenously, and reacts to trade policy shocks.

The two Kemp-Wan scenarios use a modified GTAP closure, where the tariffs applied by EPA members on each commodity imported from non-EPA regions are endogenized and the imports from non-EPA regions are made exogenous. In doing so, the endogenous tariffs will adjust to keep the imports from non-EPA regions constant at their pre-EPA levels and thus avoid trade diversion, in line with the Kemp-Wan condition. Like in the case of the base scenarios, two Kemp-Wan scenarios will be simulated: one with intra-ACP full tariff liberalization (KempWan2) and one without (Kemp-Wan1).

As in Waschik (2005, 2006), by simulating a base and a Kemp-Wan scenario, it is possible to disentangle the trade creation and trade diversion effects on nonmembers. Thus, the results of the base scenarios occur from both trade creation and diversion effects, whereas the results from the Kemp-Wan scenarios account only for trade creation. The difference between the two sets of scenarios represents the impact attributable to trade diversion only.

It should also be noted that several caveats apply to these simulations. Due to data limitations and to the fact that only a few African countries are individually included in the GTAP6 database, not all EPAs could be simulated separately. Thus, due to the structure of GTAP database, it was not possible to simulate separately three of the African EPAs (West Africa, Central Africa, Eastern and Southern Africa) ${ }^{12}$ Furthermore, EPAs are more than just tariff liberalization, as discussed in this paper. ACP and EU are trying to conceive EPAs as more than just purely trade liberalization agreements, dealing with developmental aspects and aiming to introduce "deeper" integration measures or mutual cooperation on such as competition policy and consumer protection, investment, trade facilitation and customs

\footnotetext{
${ }^{12}$ Several other limitations and caveats should be made in connection to the use of CGE models in the case of African countries. For a detailed discussion see Hammouda and Osakwe (2006).
} 
cooperation, government procurement, as well as dispute settlement, standards (TBT, SPS), intellectual property rights, genetic resources, traditional knowledge and folklore. The Pacific has proposed an investment cooperation agreement to encourage inflow of EU investment in the Pacific. Therefore the welfare impact of EPA formation should not be considered as a comprehensive assessment. Another overlooked aspect is that preferential market access is affected by less than full utilization rates of such preferential access. The utilization rates data is not available for all the RTAs included in GTAP but existing data suggest that sometimes low utilization rates may significantly reduce the impact of RTA formation.

\section{B. Simulation Results}

In all scenarios, we investigate the potential for trade creation and diversion due

Table 5. Welfare Results, by Scenario (Equivalent Variation, in \$US million and per cent)

\begin{tabular}{|c|c|c|c|c|c|c|c|c|}
\hline & \multicolumn{2}{|l|}{ Base1 } & \multicolumn{2}{|l|}{ Base2 } & \multicolumn{2}{|c|}{ Kemp-Wan 1} & \multicolumn{2}{|c|}{ Kemp-Wan 2} \\
\hline & (\$US million) & $\%$ & (\$US million) & $\%$ & (\$US million) & $\%$ & (\$US million) & $\%$ \\
\hline$\overline{\text { Ocean_Dev }}$ & -126.7 & -0.1 & -133.2 & -0.2 & -62.6 & -0.1 & -61.9 & -0.1 \\
\hline Pacific & 94.6 & 0.9 & 146.7 & 1.5 & 542.1 & 10.4 & 697.2 & 13.4 \\
\hline China & -109 & -0.1 & -128.9 & -0.1 & -12.8 & -0.1 & -17.3 & -0.1 \\
\hline Asia_Dev & -366.7 & -0.1 & -443.6 & -0.1 & -170.9 & -0.1 & -204 & -0.1 \\
\hline EastAsia & -86.7 & -0.1 & -94.4 & -0.1 & -41.5 & -0.1 & -40.7 & 0 \\
\hline SouthAsia & -141.4 & -0.2 & -172 & -0.2 & -38.9 & -0.1 & -43.6 & -0.1 \\
\hline NAFTA & -571.4 & -0.1 & -661.6 & -0.1 & -431 & -0.1 & -436 & -0.1 \\
\hline Andean & -61.8 & -0.1 & -57.5 & -0.1 & -27.2 & -0.1 & -23.3 & -0.1 \\
\hline Mercosur & -187.9 & -0.1 & -199.2 & -0.2 & -63.6 & -0.1 & -56.1 & -0.1 \\
\hline SouthAm & -23.8 & -0.6 & -23.7 & -0.6 & -0.3 & -0.1 & -0.2 & 0 \\
\hline CentralAm & -29.9 & -0.1 & -29.4 & -0.1 & 5.1 & 0.0 & 6.6 & 0.0 \\
\hline Caribbean & 145.4 & 0.1 & 181.5 & 0.2 & 268.8 & 0.3 & 298 & 0.4 \\
\hline EU & 5181.7 & 0.2 & 5010.6 & 0.2 & 3864.2 & 0.0 & 3934 & 0.04 \\
\hline EFTA & -137.8 & 0.0 & -136.3 & 0.0 & -63.8 & -0.1 & -53.1 & -0.1 \\
\hline Europe_R & -51.5 & -0.1 & -56.6 & -0.1 & -8.6 & 0.0 & -7.5 & 0 \\
\hline CIS & -119.6 & 0.0 & -109.5 & 0.0 & -52.7 & -0.1 & -49.1 & -0.1 \\
\hline Med & -349.8 & -0.1 & -332.6 & -0.1 & -179 & -0.1 & -151.3 & -0.1 \\
\hline SADC & 526 & 0.0 & 772.3 & 0.5 & 1411 & 1.7 & 1497.3 & 1.9 \\
\hline RoA & -186.5 & -2.0 & -37 & -1.7 & -806.4 & -4.5 & -757.2 & -4.4 \\
\hline RoW & -4.3 & -0.3 & -4.3 & -0.3 & -40.9 & -3.1 & -36.5 & -2.8 \\
\hline Total & 3392.8 & & 3491.2 & & 4091 & & 4495.5 & \\
\hline
\end{tabular}

Source: Model results. 
to tariff removal between ACP regions and the EU. Welfare results of these simulations (expressed as equivalent variation) are reported in Table 5. With the exception of Rest of Africa (RoA), that would suffer from significant terms of trade losses and investment-savings balance effects, the simulation results suggest an increase in welfare in all other EPA regions, with values ranging from \$US 94.6 in the base scenario in the Pacific region to over \$US 5 billion in the EU in the base 2 scenario.

In percentage terms, the largest welfare improvements occur in the in the KempWan2 scenario (Pacific region 13.4 per cent and SADC 1.9 per cent). Generally, intra-ACP trade liberalization leads to an increase in welfare in all regions (base2 compared to base1 scenario, and Kemp-Wan2 compared to Kemp-Wan1 scenario). As we would expect, all non-members are worse off due to trade diversion (i.e. the welfare losses are systematically higher in the base scenario than the corresponding Kemp-Wan scenario). But, regardless of scenario, the welfare effects for non-EPA members are marginal, with usually a reduction by -0.1 per cent in the welfare level prior to EPA formation. Apart from non-EPA members, the Rest of Africa would also see its welfare level reduced, between -1.7 per cent (base2 scenario) and -4.4 per cent (Kemp-Wan2 scenario).

Welfare losses of non-members due solely to trade diversion (the difference between the base and the Kemp-Wan scenarios) are also very small, suggesting that trade diversion would not be a major concern in the case of EPA, even in the case of exogenous tariffs. These results with respect to small welfare losses for non-members lead to some potentially interesting policy recommendations that could provide a further justification for deep asymmetry in the liberalization commitments taken by the ACP countries and EU as part EPAs. One of the main implicit objectives of the drafters of the Article XXIV was to ensure that RTAs do not undermine global welfare. Hence, since third countries are not negatively affected by the EPAs in any significant way, and since the jurisprudence on Article XXIV is not settled, these findings provide an empirical base for the position adopted by ACP countries on this particular issue in the current Doha Round. ${ }^{13}$

The welfare results presented in the previous section can be decomposed into distinct sources. Allocative efficiency, terms of trade effects, and investmentsavings price effects are the major determinants of welfare changes. In both KempWan scenario, for the EU and Caribbean, the allocating efficiency gains are the most important. In the case of SADC, the largest welfare gains occur from terms of

\footnotetext{
${ }^{13}$ We would like to thank one of the anonymous referees for this particularly useful policy recommendation.
} 
Table 6. Endogenous Tariff Changes, under the Kemp-Wan Scenarios

\begin{tabular}{|c|c|c|c|c|c|c|c|c|c|c|}
\hline \multirow{2}{*}{$\begin{array}{l}\text { Sector } \\
\text { Region }\end{array}$} & \multicolumn{2}{|c|}{ Pacific } & \multicolumn{2}{|c|}{ Caribbean } & \multicolumn{2}{|c|}{$\overline{E U}$} & \multicolumn{2}{|c|}{ SADC } & \multicolumn{2}{|c|}{ RoAfrica } \\
\hline & Scenario 1 & Scenario 2 & Scenario 1 & Scenario 2 & Scenario 1 & Scenario 2 & Scenario 1 & Scenario 2 & Scenario 1 & Scenario 2 \\
\hline Cereals & 0.0 & 0.0 & -8 & -11 & -2 & -1 & -8 & -11 & -17 & -20 \\
\hline Sugar cane, sugar beet & -2.7 & 0.0 & -26 & -30 & -7 & -6 & -23 & -30 & -41 & -47 \\
\hline Plant-based fibers & 0.0 & 0.0 & -2 & -2 & -1 & -1 & -10 & -10 & -13 & -12 \\
\hline Forestry and Fishing & -7.9 & -6.0 & -7 & -7 & -4 & -4 & -1 & -1 & -6 & -7 \\
\hline Meat, oils, fats & -17.4 & -26.4 & -12 & -12 & -36 & -36 & -12 & -12 & -18 & -18 \\
\hline Dairy products & -17.8 & -35.6 & -14 & -16 & -21 & -21 & -18 & -18 & -17 & -19 \\
\hline Processed rice & 0.0 & 0.0 & -11 & -14 & -14 & -14 & -9 & -12 & -15 & -18 \\
\hline Textiles, clothing, leather & -11.9 & -29.7 & -12 & -12 & -2 & -2 & -14 & -14 & -22 & -22 \\
\hline Wood and paper & -9.3 & -20.6 & -10 & -11 & 0 & 0 & -10 & -11 & -16 & -17 \\
\hline Chemical,rubber,plastic prods & -11.4 & -34.4 & -8 & -9 & 0 & 0 & -6 & -8 & -13 & -14 \\
\hline Minerals and metal products & -11.2 & -14.7 & -10 & -12 & -1 & -1 & -9 & -11 & -17 & -18 \\
\hline Other Manufactures & -9.7 & -12.9 & -9 & -10 & -1 & -1 & -8 & -9 & -12 & -14 \\
\hline
\end{tabular}

Source: GTAP simulations

Legend: Estimated Doha tariff cuts

For ACP countries, envisaged tariff cuts on agricultural products (as included in their negotiating proposals) range from 15-30 per cent, depending on the inital protection rate. For EU, envisaged tariff cuts on agricultural products (as included in their negotiating proposals) range from 20-60 per cent, depending on the inital protection rate. For NAMA, the final Doha tariff will depend on the coefficients chosen in the tariff cutting formula. 
trade effects. However, the results are rather different for Rest of Africa, which witnesses significant terms of trade losses.

Let's turn now to the reductions in tariffs to ensure that the envisaged EPAs are Kemp-Wan compatible. Table 6 below contains the maximum tariff cuts required for each sector, exporting non-EPA and EPA importing region.

As mentioned earlier, the simultaneous negotiations of EPAs and the WTO Doha Round allows us to consider that de facto EPAs have the potential to comply with Kemp-Wan criterion, should the final Doha tariff cuts be equal or larger than the endogenous tariff cuts obtained from the Kemp-Wan scenarios. This tentative comparison between endogenous EPA tariff cuts and Doha negotiations is burdened by several difficulties. Firstly, as McMillan (1993) argued, Kemp-Wan compatibility should be assessed at the most disaggregated level possible. Secondly, at this point, given the impasse in the Doha negotiations, it is rather difficult to estimate the range of final tariff cuts WTO members will agree to undertake on an MFN basis. Furthermore, WTO negotiations reduce bound tariffs, whereas the endogenous tariffs reported in Table 6 are applied tariffs, and hence the "water in the tariff" (particularly in agriculture and in the case of Sub-Saharan Africa overall) complicates even further this comparison.

However, several tentative considerations can be made with regard to the potential of Doha negotiations to render the EPAs Kemp-Wan compatible. Based on the existing negotiating positions submitted by the ACP group, the envisaged linear tariff cuts in bound rates on agricultural products would range from 15-30 per cent, depending on the initial protection rate (the higher the initial protection rate, the higher the cut). Similarly, for the EU, the envisaged tariff cuts in bound rates on agricultural products range from 20-60 per cent, depending on the initial protection rate. For NAMA, the final Doha tariff will depend on the coefficients chosen in the tariff cutting formula, which at the time of writing, were less clear than the proposals concerning agricultural negotiations. However, if one assumes the 10-15 proposal as Swiss coefficients for developed and developing countries, respectively, a comparison of the new endogenous tariffs with final applied MFN tariffs for each of the sectors concerned could be made.

For illustrative purposes, the analysis is carried out only on agricultural goods, the ones that prove a thorny issue in most RTA formation. The bold numbers in table 6 suggests sectors where the tariff cuts in the bound rates resulting from the Doha negotiations, based on the current parameters, might not be sufficient to ensure a Kemp-Wan compatible outcome. These sectors are those with Kemp-Wan 
tariff cut requirements larger than the lower-end estimated Doha tariff cuts in bound rates of 15 per cent. The number of critical sectors is an underestimate, given the "water in the tariff" currently existing for many products or the lack of bound tariffs, particularly in Sub-Saharan Africa. However, the likelihood of Doha outcome incompatible with the Kemp-Wan EPA requirements would be much lower for products requiring a 1 per cent applied tariff cut (e.g. animal products, plant-based fibers, forestry and fishing) than those requiring over 30 per cent reductions, such as sugar or dairy products. The region with the most problematic sectors is Rest of Africa, while the Caribbean and the EU are the regions with the smallest number of problematic sectors. In terms of cross-sectoral comparison, beverages and tobacco, as well as diary products seem to be the sectors where the Doha negotiations may lead to a suboptimal outcome in terms of Kemp-Wan criterion.

One other consideration should be taken into account. As mentioned in the previous section, according to the general principles used in the application of the current GATT Art. XXIV, several "sensitive sectors" can be eliminated or liberalized gradually over longer periods, without compromising the WTO compatibility, as long as the SAT requirements are respected. This is the case for sugar, for instance, which has been considered by the EU as a "sensitive sector" subject to longer transition periods. Therefore, until real liberalization occurs within EPA, even if the endogenous Kemp-Wan tariff cut required for sugar ( 65 per cent tariff cut) vis-àvis non-EPA members is not attained as part of the Doha negotiations, this will not mean that the Kemp-Wan criterion is not fulfilled, as the sectors has not been liberalized and no trade diversion occurred. The same logic could apply to other "sensitive sectors", in addition to the criteria used in the previous section to identify sectors with high degree of sensitivity.

This Kemp-Wan logic of sectoral exclusion may be an alternative to the existing "catch me if you can" logic prevailing in the current negotiations aimed at making the GATT Art. XXIV rules more stringent.

\section{Conclusions}

The analysis undertaken in this paper illustrated a few clear methodological points that could be followed by WTO members in order to derive sound policy guidance, as far as existing proposals for WTO compatibility of RTAs is concerned. In the case of the SAT requirements, the partial equilibrium analysis should be 
performed on a case by case basis, for each ACP sub-grouping involved in EPA negotiations. This methodology can also be used for a more careful analysis of possible specificities and particular needs of individual countries that are part of each sub-regional integration grouping.

In the case of the Tanzania example discussed above, for instance, the following conclusions were derived. Firstly, the analysis has shown that identifying "sensitive products" while complying with "substantially all trade" criterion can be done by using various development benchmarks to select the "sensitive" sectors. Similarly, it has shown that some of the SAT conditions are, at least in the case of Tanzania, easier to comply with than others. However, some newly proposed SAT criteria, in particular the "highly traded products" criterion, would significantly reduce the flexibility available to ACP countries to negotiate WTO-compliant EPAs.

Another important conclusion of this analysis is that if a cautious liberalization approach is favoured by a particular ACP country, a line-by-line approach is more appropriate in tailoring EPAs to the specific development needs of ACP States than using an overall import surge criterion.

One further complication arises in the case of the SAT criteria for EPAs. EPAs, unlike most existing RTAs would be a grouping-to-grouping RTA. This requires a further clarification of the SAT requirements. For instance, all SAT requirements (80 per cent of total trade, 70 per cent of tariff lines, "highly traded products", "significant exports", etc.) could be defined at group level or at country level. So far, at least as part of the WTO RTA examination process, there are no cases of grouping-to-grouping RTA being examined and assessed in terms of "substantially all trade" or other GATT Article XXIV conditions. In the absence of such precedent, one could assume that SAT requirements should apply at group level (e.g. across Eastern and Southern Africa or Caribbean regions) rather than at the level of each country member of the particular ACP sub-grouping forming an EPA. This approach is justified by at least two reasons. Firstly, in the case of the EU, in all examinations the SAT requirement is considered at group level and not at country level. Therefore, any ACP sub-grouping currently forming, or aiming for, a custom union or a more advanced form of regional integration should also comply with the SAT requirements as a group. This would introduce additional flexibility to some ACP countries, at least in the transition period. Secondly, EPAs are bilateral agreements signed by various groups of ACP countries on one side, and the EU on the other. EPAs are not and therefore, for the purpose of SAT requirements or any other GATT Article XXIV conditions should not be considered as a hub-and-spoke 
combination of bilateral agreements but rather as a single bilateral agreement.

One way to make these SAT requirements more ACP-friendly, would be to assess the impact of different threshold values for each requirement, in addition to the ones contained in the Australian submission. For instance "highly traded products" could be defined as products accounting for 1 per cent or 2 per cent of intra-RTA trade, with numerical targets to be tailored to each ACP EPA regional configuration. By relaxing the definition of "highly traded products" this criterion could be taken on board, while preserving the "policy space" needed by ACP countries.

Finally, ACP countries could come up with their own proposals to define special and differential flexibility on SAT requirements, based on the various benchmarks discussed above, or various other SDT elements can also be considered.

As an alternative to the current debates on the reform of the GATT Art. XXIV, this paper used an empirical way to assess the compatibility of future EPAs with a well-known theoretical benchmark: the Kemp-Wan theorem. This theoretical prediction has an indirect practical value since the EPA negotiations are taking place in parallel with the Doha negotiations and thus MFN tariff reductions may eliminate the negative welfare effects associated with trade diversion. Based on a CGE model with endogenous tariffs, the paper argued that the potential for trade diversion and welfare losses for non-EPA members is quite limited. However, as predicted in the literature and in line with other simulations of EPAs, the results suggest that the Kemp-Wan endogenous tariff condition is not sufficient to "lift up all the boats": the "Rest of Africa" region may experience non-negligible welfare losses and a severe deterioration in its trade performance as a result of EPA formation.

When looking at the sectoral disaggregation of the endogenous tariff cuts necessary for Kemp-Wan compatibility, in a few sectors the tariff cuts envisaged in the Doha negotiations seem to be insufficient. Therefore, instead of focusing on a "catch me if you can" approach to the reform of the GATT Art. XXIV, WTO members could find a common ground in the Kemp-Wan compatibility criterion, which would allow not only the needed development flexibility for developing countries willing to form North-South RTAs, but also a more beneficial outcome for the rest of the world.

\section{Acknowledgements}

The authors would like to thank the participants to the $10^{\text {th }}$ GTAP Annual 
Conference, and in particular Terrie Walmsley and two anonymous referees, for their very useful comments and suggestions.

Received 30 June 2007, Revised 7 March 2008, Accepted 8 April 2008

\section{References}

Bond E., Riezman, R. and Syropoulos, C. (2004) "A Strategic and Welfare Theoretical Analysis of Free Trade Areas", Journal of International Economics, 64, 1-27.

Brenton, P., Hoppe, M., and Newfarmer, R. (2007). "EPAs and Export Competitiveness of Africa," International Trade Department, World Bank

Gilbert, J. and Wahl, T. (2001) “Assessing China's Potential Role in Asia's New Regionalism”, Paper presented at the Conference "Agricultural Trade with China in the New Economic and Policy Environment", Sonoma, California, April 2001.

Grant, J., Hertel, T. and Rutherford, T. (2007) "Extending General Equilibrium to the Tariff Line: US Dairy in the Doha Development Agenda", Paper presented at the 10th Annual Conference on Global Economic Analysis, Purdue University, USA.

Hammouda, H. B. and Osakwe, P. (2006) "Global Trade Models and Economic Policy Analyses: Relevance, Risks and Repercussions for Africa", ATPC Work in Progress No. 47, Economic Commission for Africa, December.

Hertel, T. (1997). Global Trade Analysis: Modeling and Applications, Cambridge: Cambridge University Press.

Kemp, M.C. and Wan, H. (1976). "An Elementary Proposition Concerning the Formation of Customs Unions", Journal of International Economics, 6, 95-8.

Laird, S. and Yeats, A. (1986) "The UNCTAD Trade Policy Simulation Model: A Note on the Methodology, Data and Uses", Working Paper no. 19, United Nations: Geneva.

McMillan, J. (1993), "Does Regional Integration Foster Open Trade? Economic Theory and GATT's Article XXIV" in Anderson, K. and R. Blackhurst (eds.) Regional Integration and the Global Trading System London: Harvester-Wheatsheaf.

Panagariya, A. and Krishna, P. (1997) "On the Existence of Necessarily Welfare-Enhancing Free Trade Areas", Working Paper No.32, Center for International Economics, University of Maryland.

Pomfret, R.W.T. (2002), "State-Directed Diffusion of Technology: The Mechanization of Cotton-Harvesting in Soviet Central Asia", Journal of Economic History, Volume 62, Issue 01. March 2002. pp170-188.

Stevens, C. and Kennan, J. (2005) "Preparing for Economic Partnership Agreements: Trade Analysis Handbook", Institute of Development Studies, University of Sussex, Brighton.

Karingi, S., Lang, R., Oulmane, N., Perez, R., Jallab, M. S., Hammouda, B. H. (2005) "Economic and Welfare Impacts of the EU-Africa Economic Partnership Agreements", African Trade Policy Centre, ATPC Work no. 10, United Nations Economic Commission 
for Africa, Adis Abbaba.

Waschik, R. (2005) "Trade Creation, Trade Diversion, and Non-Members of Free Trade

Areas La Trobe University, Victoria, Australia, May, mimeo.

Waschik, R. (2006) "Modelling Kemp-Vanek Admissibility: The Effects of Free Trade

Areas on Non-Members", La Trobe University, Victoria, Australia, May, mimeo.

\section{Annex 1. Regional and Sectoral Aggregations}

Regional aggregation

\begin{tabular}{|c|c|}
\hline Code & Comprising \\
\hline Ocean_Dev & Australia; New Zealand. \\
\hline Pacific & Rest of Oceania. \\
\hline China & China; Hong Kong. \\
\hline Asia_Dev & Japan; Korea; Taiwan; Singapore. \\
\hline EastAsia & $\begin{array}{l}\text { Rest of East Asia; Indonesia; Malaysia; Philippines; Thailand; Vietnam; Rest } \\
\text { of Southeast Asia. }\end{array}$ \\
\hline SouthAsia & Bangladesh; India; Sri Lanka; Rest of South Asia. \\
\hline NAFTA & Canada; United States; Mexico. \\
\hline Andean & Colombia; Peru; Venezuela; Rest of Andean Pact. \\
\hline Mercosur & Argentina; Brazil; Chile; Uruguay. \\
\hline SouthAm & Rest of South America. \\
\hline CentralAm & Central America. \\
\hline Caribbean & Rest of FTAA; Rest of the Caribbean. \\
\hline EU & $\begin{array}{l}\text { Austria; Belgium; Denmark; Finland; France; Germany; United Kingdom; } \\
\text { Greece; Ireland; Italy; Luxembourg; Netherlands; Portugal; Spain; Sweden; } \\
\text { Bulgaria; Cyprus; Czech Republic; Hungary; Malta; Poland; Romania; Slova- } \\
\text { kia; Slovenia; Estonia; Latvia; Lithuania. }\end{array}$ \\
\hline EFTA & Switzerland; Rest of EFTA. \\
\hline Europe_R & Rest of Europe; Albania; Croatia; Turkey. \\
\hline CIS & Russian Federation; Rest of Former Soviet Union. \\
\hline Med & Rest of Middle East; Morocco; Tunisia; Rest of North Africa. \\
\hline SADC & $\begin{array}{l}\text { Botswana; South Africa; Rest of South African CU; Malawi; Mozambique; } \\
\text { Tanzania; Zambia; Zimbabwe; Rest of SADC; Madagascar; Uganda. }\end{array}$ \\
\hline RoA & Rest of Sub-Saharan Africa. \\
\hline RoW & Rest of North America. \\
\hline
\end{tabular}


Sectoral aggregation

\begin{tabular}{|c|c|}
\hline Description & Comprising \\
\hline Cereals & Paddy rice; Wheat; Cereal grains nec. \\
\hline Vegetables, fruit, nuts & Vegetables, fruit, nuts; Oil seeds. \\
\hline Sugar cane, sugar beet & Sugar cane, sugar beet. \\
\hline Plant-based fibers & Plant-based fibers. \\
\hline Crops nec & Crops nec. \\
\hline Animal products & $\begin{array}{l}\text { Cattle,sheep,goats,horses; Animal products nec; Raw milk; } \\
\text { Wool, silk-worm cocoons. }\end{array}$ \\
\hline Forestry and Fishing & Forestry; Fishing. \\
\hline Oil and minerals & Coal; Oil; Gas; Minerals nec. \\
\hline Meat, oils, fats & $\begin{array}{l}\text { Meat: cattle,sheep,goats,horse; Meat products nec; Vegeta- } \\
\text { ble oils and fats. }\end{array}$ \\
\hline Dairy products & Dairy products. \\
\hline Processed rice & Processed rice. \\
\hline Sugar & Sugar. \\
\hline Beverages and tobacco products & Food products nec; Beverages and tobacco products. \\
\hline textiles, clothing, leather & Textiles; Wearing apparel; Leather products. \\
\hline wood and paper & Wood products; Paper products, publishing. \\
\hline Chemical,rubber,plastic prods & Petroleum, coal products; Chemical,rubber,plastic prods. \\
\hline Minerals and metal prod & $\begin{array}{l}\text { Mineral products nec; Ferrous metals; Metals nec; Metal } \\
\text { products. }\end{array}$ \\
\hline Manufactures & $\begin{array}{l}\text { Motor vehicles and parts; Transport equipment nec; Elec- } \\
\text { tronic equipment; Machinery and equipment nec; Manu- } \\
\text { factures nec. }\end{array}$ \\
\hline Services & $\begin{array}{l}\text { Electricity; Gas manufacture, distribution; Water; Construc- } \\
\text { tion; Trade; Transport nec; Sea transport; Air transport; } \\
\text { Communication; Financial services nec; Insurance; Busi- } \\
\text { ness services nec; Recreation and other services; PubAd- } \\
\text { min/Defence/Health/Educat; Dwellings. }\end{array}$ \\
\hline
\end{tabular}

